\title{
Terra, trabalho e dinheiro: dilemas e tensões da condição camponesa no assentamento santa helena
}

\author{
Diogo Marques Tafuri ${ }^{1}$ \\ Luiz Gonçalves Junior ${ }^{2}$
}

RESUMo: Neste artigo discutiremos o fenômeno da luta pela terra como meio de vida e condição camponesa
no Brasil, constituindo-se enquanto prática social geradora de processos educativos que conformam formas
de ser e de agir ao mundo dos sujeitos assentados, instituindo experiências de vida individuais e coletivas
condicionadas por tal realidade. Nosso foco de investigação voltou-se para a compreensão das tensões vi-
venciadas nos últimos anos desta década pelos/as agricultores/as orgânicos/as do Assentamento "Projeto de
Desenvolvimento Sustentável Santa Helena", implantado em 2005 no município da São Carlos/SP. Por meio
da análise fenomenológica dos dados coletados em campo, discutimos aspectos relacionados às formas de
trabalho engendradas no assentamento, às relações comerciais e financeiras estabelecidas pelos agricultores/
as em seu cotidiano de vida e à forma com que significam o manejo orgânico da terra. Argumentamos que tais
experiências educativas se expressam e são marcadas presentemente pelo processo continuado de recriação
de constrangimentos sociais que em parte caracteriza a realidade dos assentamentos rurais contemporâneos.

Palavras-Chave: Processos Educativos. Luta pela Terra. Assentamentos Rurais. Questão Agrária.

\section{LAND, WORK AND MONEY: DILEMMS AND TENSIONS OF THE PEASANT CONDITION IN THE SETTLEMENT SANTA HELENA}

AвSTRACT: In this paper we will discuss the phenomenon of the struggle for land as a way of life and a peasant condition in Brazil. It constitute itself as a social practice that generates educational processes that promote ways of being and acting in the world of the farmers, instituting individual and collective experiences conditioned by this reality. Our research focus turned to understanding the tensions experienced in the last years of this decade by organic farmers from the Santa Helena settlement, a Sustainable Development Project, implemented in 2005 in the city of São Carlos / SP. Through phenomenological analysis of the data collected in the field, we discussed aspects related to the forms of work generated in the settlement, the commercial and financial relations established by farmers in their daily lives and the way in which each other means the organic management of the land. We argue that such educational experiences are expressed and registred by the continued process of recreating social constraints that partly characterizes the reality of contemporary rural settlements.

KeYwords: Educational Processes. Struggle for Land. Rural Settlements. Agrarian Issue.

\footnotetext{
${ }^{1}$ Bacharel em Ciências Sociais pela Universidade de São Paulo (2007), Mestre (2014) e Doutor (2019) em Educação pela Universidade Federal de São Carlos. Integra o quadro de sócios da Cooperativa de Trabalho e Assessoria Técnica, Extensão Rural e Meio Ambiente (AMATER). E-mail: diogotafuri@gmail.com

${ }^{2}$ Professor Titular do Departamento de Educação Física e Motricidade Humana da Universidade Federal de São Carlos (DEFMH/UFSCar). Professor do Programa de Pós-Graduação em Educação (PPGE) da UFSCar. E-mail: luizgjr@feb.unesp.br
} 


\section{INTRODUÇÃo}

Buscamos neste artigo discutir o fenômeno da luta pela terra como meio de vida e condição camponesa no Brasil, constituindo-se enquanto prática social geradora de processos educativos que conformam formas de ser e de agir ao mundo das pessoas que nela estão envolvidas (OLIVEIRA et al, 2014), instituindo experiências de vida individuais e coletivas que, para os sujeitos assentados, se expressam presentemente no seio do processo perene de recriação de constrangimentos sociais que em parte caracteriza a realidade dos assentamentos rurais contemporâneos. Nosso foco de investigação voltou-se para a compreensão da realidade de lutas e de tensões vivenciadas nos últimos anos desta década por agricultores/ as de um assentamento rural de São Carlos, interior do estado de São Paulo: o Projeto de Desenvolvimento Sustentável (PDS) ${ }^{1}$ Santa Helena, implantado neste município em 2005 sob a responsabilidade do Instituto Nacional de Colonização e Reforma Agrária (INCRA), o qual viabilizou a cessão de uso de lotes com aproximadamente 5,4 hectares às 14 famílias que ali se encontraram acampadas tendo em vista a conquista da terra.

O Assentamento Santa Helena está inserido em uma mesma conjuntura agrária característica da região central do estado de São Paulo, marcada pela alta concentração da propriedade fundiária e pela predominância da monocultura de commodities agrícolas com grande aporte tecnológico (especialmente no complexo agroindustrial sucroalcooleiro). Dentro de tal contexto, o PDS Santa Helena, assim como outros assentamentos rurais paulistas, convivem habitualmente com as pressões exercidas por setores sociais críticos da política de cessão de terras via constituição de assentamentos rurais, especialmente no que tange à eficiência econômico-financeira de tais agrupamentos e seu papel na promoção do desenvolvimento econômico da região (FERRANTE; BARONE; DUVAL, 2012). De forma específica, limitamos nossa pesquisa à associação de 08 famílias assentadas vinculadas à Organização de Controle Social (OCS)2 criada no assentamento em 2013, a partir do Programa de Certificação de Agricultura Orgânica realizado pelo Serviço Nacional de Aprendizado Rural de São Paulo (SENAR/SP), em parceria com o Ministério da Agricultura, Pecuária e Abastecimento (MAPA). Com este

\footnotetext{
${ }^{1}$ Os assentamentos rurais da categoria PDS destinam-se, de acordo com as normativas do INCRA, ao manejo sustentável e a preservação de reservas de matas primárias por populações que repousam seu sustento no extrativismo e em atividades de baixo impacto ambiental, tais como o comércio de mudas florestais, cascas medicinais, sementes, artesanato, resina, cipó, entre outros. De acordo com Arruda (2017): "A Portaria INCRA n. 477 de 1999, que deu origem aos PDSs, veio responder à reivindicação dos movimentos sociais da região amazônica e buscou compatibilizar o desenvolvimento de atividades produtivas à conservação de recursos naturais, orientar a ocupação das áreas dos PDSs tendo em vista a sustentabilidade das atividades produtivas e até mesmo a recomposição do potencial dos recursos naturais originais" (p. 28).

${ }^{2}$ Forma participativa de certificação da qualidade orgânica da produção agrícola, formalizada pela Lei n $10.831 / 2003$, e regulamentada pelo Decreto ${ }^{\circ}$ 6323/2007, Instrução Normativa n 46/2011, que estabelece o regulamento técnico para os Sistemas Orgânicos de Produção Animal e Vegetal, bem como as Listas de Substâncias Permitidas.
} 
grupo de produtores/as rurais temos realizado, desde 2015, trabalho de assessoria técnica para comercialização coletiva de seus produtos agrícolas orgânicos, inicialmente por meio de projeto de extensão executado pelo Núcleo Multidisciplinar Integrado de Estudos, Formação e Intervenção em Economia Solidária da Universidade Federal de São Carlos (NuMI-EcoSol/ UFSCar), e depois como membro da Cooperativa de Trabalho e Assessoria Técnica, Extensão Rural e Meio Ambiente (AMATER).

Entre os meses de junho e julho de 2017, após dois anos de convívio com os/as agricultores/as e de aproximação gradativa com a realidade do assentamento, realizamos entrevistas individuais semiestruturadas com uma pessoa de cada propriedade familiar de produção orgânica do assentamento, por meio das quais dialogamos acerca das distintas trajetórias de luta pela terra experienciadas por eles/as ao longo de suas vidas, assim como sobre as condições em que vinha se realizando o trabalho agrícola no assentamento. Para análise das descrições obtidas acerca do referido tema, bem como sua posterior formulação na forma de compreensões significativas sobre a estrutura do fenômeno estudado, percorremos dois momentos distintos e conjugados da análise fenomenológica, o ideográfico e o nomotético, realizando o reagrupamento de constitutivos relevantes do fenômeno interpretado a partir da depuração, proporcionada pelas leituras das entrevistas, de categorias gerais relevantes. Tal exercício foi realizado por meio do levantamento e interpretação das unidades de significado identificadas nas descrições de campo (análise ideográfica) e do reconhecimento de seus aspectos convergentes e divergentes (análise nomotética), possibilitando o desvelamento de uma perspectiva do fenômeno3 (GARNICA, 1997; MARTINS; BICUDO, 1989).

Tomando o caráter histórico da existência de homens e mulheres como condição inata à natureza humana, é no seio do estudo do processo de elaboração do mundo cultural, entendido como totalidade que abarca as relações complexas de constituição mútua entre o processo social de produção material e o processo social de produção simbólica, que buscamos compreender as práticas sociais empreendidas pelos colaboradores/as desta investigação enquanto fenômeno que institui uma educação propriamente camponesa. Na esteia de Carlos Rodrigues Brandão (2002):

\footnotetext{
${ }^{3}$ Segundo Garnica: "Na análise Ideográfica, o pesquisador procura por unidades de significado, o que faz após várias leituras de cada uma das descrições (...) Articulando as compreensões que resultaram dessa seleção das unidades de significado e das próprias unidades, o pesquisador trata de agrupá-las em categorias mediante reduções (...) A análise nomotética é feita com base na análise das divergências e convergências expressas pelas unidades de significado, estando vinculada, ainda, a interpretações que o pesquisador faz para obter cada uma dessas convergências ou divergências. Disso, novos grupos são formados e, num processo contínuo de convergências e interpretações, sempre explicitadas, novas categorias abertas, mais gerais, vão-se formando. As generalidades resultantes dessa análise iluminam uma perspectiva do fenômeno, dado seu caráter perspectival” (GARNICA, 1997, pp. 116-117).
} 
[...] tudo o que se passa no âmbito daquilo a que nos acostumamos a dar o nome de educação, acontece também dentro de um âmbito mais abrangente de processos sociais de interações chamado cultura [...] A educação é, também, uma dimensão ao mesmo tempo comum e especial de tessitura de processos e produtos, de poderes e de sentido, de regras e de alternativas de transgressão de regras, de formação de pessoas como sujeitos de ação e de identidade e de crises de identificados, de invenção, de reiteração de palavras, valores, ideias e de imaginários com que nos ensinamos e aprendemos a sermos quem somos e a sabermos viver com a maior e mais autêntica liberdade pessoal possível os gestos de reciprocidade social que a vida social nos obriga (p. 25).

Se, por um lado, "[...] às intenções do sujeito que age na história o mais das vezes não correspondem os resultados originalmente visados porque esse sujeito, embora agente, nunca é senhor da situação em que age", de forma recíproca, "esse mesmo sujeito pode, através da liberdade possível, resistir às pressões objetivas ou transformá-las a partir da sua subjetividade singular" (LEOPOLDO; SILVA, 2008: 161). É em vista deste equilíbrio instável existente entre as dimensões subjetiva, objetiva e intersubjetiva da existência humana que afirmamos ser a condição camponesa constituída pela experiência educativa vivenciada pelos/as agricultores e agricultoras na relação estabelecida com a terra de trabalho ao longo de suas distintas trajetórias de vida, sendo historicamente condicionada pelas formas concretas de apropriação e distribuição com que se objetifica a estrutura fundiária no Brasil e, deste modo, também pelo modo de manifestação das relações de trabalho em cada contexto espaço-temporal específico, marcado de forma comum pela concentração da propriedade de terras e pela superexploração da mão-de-obra rural e urbana.

O texto está organizado em seis partes distintas: além desta introdução (I), apresentaremos suscintamente as condições iniciais de implantação do Assentamento PDS Santa Helena vivenciadas pelos agricultores/as recém-assentados, findado o processo de conquista da posse da terra (II); em seguida, passaremos para apresentação das categorias resultantes da análise dos dados de campo, em que discutiremos aspectos relacionados às formas de trabalho engendradas no assentamento (III), às relações financeiras e comerciais estabelecidas pelos agricultores/ as em seu cotidiano de vida (IV) e à forma com que significam o manejo orgânico da terra (V); por fim, ressaltaremos elementos relevantes para a compreensão do fenômeno da luta pela terra enquanto meio de vida, prática social geradora de processos educativos que constitui a condição camponesa presente em assentamentos rurais contemporâneos, a qual é marcada pelo processo continuado de 
recriação de constrangimentos sociais (VI).

\section{“TODO COMEÇO É DIFÍCIL”: CONQUISTA-SE A TERRA, PERMANECE A LUTA"}

Ao anseio de plantar e produzir o alimento concebido pelos/as agricultores e agricultoras que lograram se estabelecer no Assentamento Santa Helena (o qual fora permeado de grande expectativa e esperança em função da motivação gerada pelo fim do desgastante e violento processo de conquista da posse da terra e também pelo início do gradeamento e preparação do solo financiado pelo INCRA ${ }^{4}$ ), contrapuseram-se uma série carências de básicas de infraestrutura e moradia indispensáveis para a formação de cada lote familiar, bem como dificuldades relacionadas à ausência imediata de renda financeira e à necessidade indispensável de constituição de canais de comercialização para escoamento dos primeiros resultados colhidos com o plantio realizado:

Ah, foi dificultoso. Todo começo é difícil. Porque faltava quase tudo. Faltava moradia, era barraco. Faltava água, era bem pouco. Praticamente um lugar que não tem moradia e não tem água. Dá pra você imaginar que é difícil. Você com criança pequena. Todas as crianças praticamente bebês ainda. Era difícil. Porque não se tinha renda nenhuma, não tínhamos renda de lado nenhum. Tinha que sair pra trabalhar nas chácaras do lado, tinha que fazer um bico aqui, outro ali. Ir pra cidade, fazer bico. [...] Tinha dia que dava vontade de abandonar tudo e ir embora de novo. Como a gente tinha aquela fé de que a gente gosta, daquela coisa que a gente gosta mesmo de mexer. Como a gente gosta, deu pra aguentar. Falei: "Vamos ficar". Fomos fazendo nossa casinha, e foi melhorando, foi melhorando. Cada vez uma melhorada mais. Demorou um pouco. Melhorando assim, fomos saindo das dificuldades mais bravas. Mas não melhorou 100\%. Melhorou 15 a $20 \%$. É coisa que com o tempo. Se comparar com hoje, graças a Deus estamos com as casas quase todas prontas. Já acessamos o PRONAF. Estamos com nossas vendas garantidas. Graças a Deus, estamos bem. Mas, teve um começo que não foi fácil não. Foi problemático mesmo (Informação Verbal - Entrevista II) $)^{5}$.

\footnotetext{
${ }^{4}$ Entre os auxílios de ordem prática, financeira e burocrática proporcionados pelo INCRA aos beneficiários do Programa Nacional de Reforma Agrária instalados no Assentamento Santa Helena, incluíram-se neste momento a preparação do solo exaurido pelo monocultivo da cana-de-açúcar ao longo dos anos (gradeamento, aplicação de calcário, etc.), a medição oficial dos lotes concedidos aos agricultores/as e seu cadastro no Sistema de Informações de Projetos de Reforma Agrária (SIPRA), condição essencial para o acesso aos benefícios disponíveis aos assentados, a obtenção do Cadastro Nacional de Pessoa Jurídica (CNPJ) de produtor rural e da Declaração de Aptidão ao Pronaf (DAP), bem como a disponibilização das linhas de crédito (a fundo perdido ou não) propiciadas ou mediadas pelo INCRA, especialmente por meio das diversas modalidades do Programa Nacional de Fortalecimento da Agricultura Familiar (PRONAF) e do Crédito Instalação.

${ }^{5}$ Entrevista concedida por Oliveira, José Maria de Souza. Entrevista II [jul. 2017]. Entrevistador: D. M. T. São Carlos, 2017. 1 arquivo .mp3 (72 min.)
} 
Sempre nós queríamos fazer horta, mas não tinha água suficiente pra fazer horta. E ele [seu marido] não deixava ninguém fazer. Ficava bravo. Não deixava o povo fazer horta aqui. [...] Porque se o poço queimasse iam ter que fazer outro. Ele dizia que se fizesse horta muito grande, a bomba do poço não ia vencer e não ia ter dinheiro pra consertar. E foi o que aconteceu, a bomba queimou aqui. Aí eu mais Tereza juntamos e fomos atrás de um vereador que deu o dinheiro pra consertar, que deu outra bomba. Só o Donizete e a Terezinha que fazia porque a água deles era da represa lá, só eles trabalhavam com horta. Os outros aqui pra cima, ninguém. Todo mundo concordava. Eles eram contra nós fazermos horta ali. Até hoje tem quem é contra. Ele não deixou de jeito nenhum. Ele falava: "Vocês vão ver, vocês vão ficar sem água" (Informação Verbal - Entrevista IV) ${ }^{6}$.

A diferença da condição socioeconômica existente entre as famílias assentadas no momento da formação dos lotes agrícolas marcou, de modo geral, a maneira com que cada uma delas se relacionou e significou o período inicial de constituição do Assentamento Santa Helena, especialmente no que tange a maior ou menor dependência em relação aos recursos disponibilizados pelo INCRA para a construção das moradias, para o provimento da infraestrutura básica e para o investimento produtivo, o que se traduziu inversamente no maior ou menor tempo decorrido para que cada uma dessas necessidades fosse suprida nos 14 lotes ali distribuídos. A estabilidade do recebimento de benefícios sociais tais como aposentadoria e a pensão, ou mesmo a utilização de recursos auferidos durante o período de vida anterior, permitiram a algumas famílias atravessarem este tempo de consolidação do assentamento de forma menos precária, podendo realizar investimentos que estavam além daqueles oferecidos pelo INCRA ou que demoravam mais do que a premência das necessidades familiares permitia.

Ademais, durante o período de realização de entrevistas com os/as produtores/ as orgânicos/as do assentamento, no inverno de 2017, a insuficiência dos recursos hídricos coletivos disponíveis aos agricultores/as ainda se constituía em entrave para promoção da horticultura no assentamento, especificamente para aqueles que não tiveram condições financeiras de realizar investimento para instalação de poços particulares, instituindo para estes um difícil conflito de escolha entre a utilização da água para realização do plantio ou para o consumo humano. Entre a ausência das condições adequadas e a impossibilidade de realização plena da atividade agrícola, as safras e colheitas viabilizadas durante os dez primeiros anos de assentamento serviram, fundamentalmente, para o autoconsumo e suprimento

${ }^{6}$ Entrevista concedida por Silva, Maria de Lourdes Carvalho. Entrevista IV [jun. 2017]. Entrevistador: D. M. T. São Carlos, 2017. 1 arquivo .mp3 (115 min.) 
parcial das necessidades básicas das famílias aliado a um pequeno comércio de excedente, dada que a estruturação de canais de comercialização mais estáveis e de maior vigor para escoamento da produção, além de necessitar de um tempo estendido para que pudessem ser prospectados e viabilizados, encontrava-se por seu turno limitada exatamente pela instabilidade das condições de produção disponíveis aos assentados, ainda que isso tenha se manifestado de forma desigual entre os lotes familiares.

Deste modo, em um primeiro e longo momento, instaurou-se para alguns/mas agricultores/as outro conflito de escolha entre a dedicação exclusiva do trabalho familiar para a formação da lavoura e reprodução do lote agrícola, e a evasão de mão de obra visando a geração de renda no curto prazo. Conforme veremos a seguir, dada a própria natureza do trabalho da roça, incessante e desgastante, a perda da capacidade de trabalho de um ou mais membros da família pode ser decisivo na viabilidade ou não da consolidação dos assentamentos rurais como lócus de vida, produção e trabalho para homens e mulheres do campo.

\section{“AQUi É UM TRABALHO FAMILIAR"}

"Nos dias de hoje a gente até agradece porque tem bastante. O que nós precisamos são de pessoas dispostas para estar na terra, pra trabalhar. Falta esse alguém com força e disposição pra trabalhar” (Informação Verbal - Entrevista VI) ${ }^{7}$. “Aqui é um trabalho familiar. Temos que fazer de um jeito que nós damos conta. Tem que ser assim, pra eu e ele dar conta do recado. Trabalhamos bastante. Trabalhamos dobrado, mas estamos dando conta" (Informação Verbal - Entrevista VII) ${ }^{8}$. As compreensões propostas acima acerca da forma com que se dá trabalho familiar nos lotes agrícolas do Assentamento Santa Helena constituem-se um ponto de partida significativo para introduzirmos as tensões que a construção da categoria "aqui é um trabalho familiar" pretende problematizar: a maneira como os/as agricultores/as assentados/as se educam no contexto da dura e incessante (e também prazerosa, preocupante, corrida) rotina de trabalho oriunda das atividades agropecuárias desenvolvidas em seus respectivos lotes, da qual decorre a realização de arranjos possíveis da mão de obra familiar em relação ao cumprimento das atribuições necessárias para a realização e venda do plantio visando a geração de renda (atividades nem sempre coincidentes), bem como o modo como é pensada e realizada a incorporação de mão de obra externa para atendimento das demandas de trabalho não atendidas pela própria família.

\footnotetext{
${ }^{7}$ Entrevista concedida por Duque, Sebastião da Frota. Entrevista VI [jul. 2017]. Entrevistador: D. M. T. São Carlos, 2017. 1 arquivo .mp3 (112 min.)

${ }^{8}$ Entrevista concedida por Silva, Maria Aparecida Rosa. Entrevista VII [jul. 2017]. Entrevistador: D. M. T. São Carlos, 2017. 1 arquivo .mp3 (70 min.)
} 
Como estou começando, essa parte de não ter condições de pagar alguém pra ajudar. Minha filha acorda 5 h30 pra ir pra escola. Meu dia já começa. Já levanto, já dou umas coisinhas pra criação, ajeito tudo e já saio pra horta. Mais ou menos umas $6 \mathrm{~h}$, as vezes as $7 \mathrm{~h} 30$ ou $8 \mathrm{~h}$ ainda estou na horta ainda. Então é corrido. É muito corrido. Espero que daqui uns dias consiga colocar um companheiro pra ajudar, pra dar uma normalizada. É corrido. Pra dar conta. Horta, você sabe. Tem serviço demais. Tem que colher todo dia, plantar, carpir. É direto. Todo dia tem que mexer. Não é igual as plantações que a gente mexia, que cuidava ali, dois três meses depois voltava pra mexer, dava outra carpa. A plantação que a gente fazia era plantação demorada de produzir, de 4 a 6 meses pra produzir. Milho, arroz, feijão, café. Você ia lá mexia e voltava só depois. A horta não, a horta tem serviço todos os dias. Todo dia tem serviço pra fazer o mesmo serviço: planta, colhe, carpe. A horta é serviço que não acaba mais. O serviço da horta não é fácil não. Agora que as crianças entram em férias, as crianças, a filha mais velha, dá uma mão. A mulher esta aí pra ajudar e dá pra dar uma descansada. [...] Você tem que fazer tudo. Tem que trabalhar aqui dentro. Tem que sair pra vender. Separar os produtos tudinho. Sair pra fazer as entregas. Sair pra feira. Sair atrás de insumos. Tem que reparar ele, pra depois levar para os canteiros. Tem gente que chega e pergunta se eu trabalho sozinho na horta, eu falo que trabalho sozinho, chega a olhar desconfiado. Eu falo. A horta é até boa aqui. Não acreditam. Eu trabalho dia e noite aqui. Até quase metade da noite. Eu tenho esperança de ter uma renda melhor pra por alguém pra ajudar. Mas a gente que gosta mesmo de estar aqui, foi criado e nasceu, sabe que o serviço da roça é pesado mesmo. Tem que resistir (Informação Verbal - Entrevista II).

Aos olhos daqueles/as que não possuem uma trajetória de vida ligada à terra e ao hábito do trabalho agrícola, o dia-a-dia corrido e atribulado inerente à própria forma multifacetada com que se dá atualmente a reprodução da vida em uma pequena propriedade rural de cunho familiar parece demasiadamente pesado e penoso de se sustentar ao longo dos dias. Objetivamente, esta rotina de trabalho envolve uma dedicação habitual que quase sempre antecede o crepúsculo matutino e ultrapassa o ocaso solar, período em que são realizadas de forma entrelaçada atividades de caráter produtivo, comercial e doméstico necessárias à reprodução da vida e do manejo da terra nos lotes, engendrando uma variedade complexa de arranjos em relação à atribuição de responsabilidade entre os membros da família para o cumprimento dos diversos afazeres diários.

Um primeiro aspecto que nos parece relevante destacar refere-se à centralidade que a horticultura adquiriu no sistema de produção do Assentamento Santa Hele- 
na, dado que os curtos ciclos produtivos de algumas hortaliças permitem, por um lado, que uma parte do que é produzido tenha uma rápida capacidade de reversão monetária. Por outro lado, tal escolha pode se apresentar de maneira controversa, considerando que os dois principais obstáculos que se ergueram aos assentados ao que se refere à possibilidade de desenvolvimento e consolidação de um sistema produtivo perene, a saber, a falta de água para irrigação e a insuficiência da mão de obra familiar para suprimento das atividades de trabalho nos lotes, são condições fundamentais para a viabilidade da implantação da horticultura em escala comercial, dada a maior necessidade de água e de manejo requerida diariamente pelo trato das hortaliças. Entretanto, o reconhecimento das limitações e da dureza do trabalho parece vir acompanhado dos aprendizados proporcionados pela experiência passada de luta, os quais expõem aos próprios sujeitos o imperativo da firmeza da intenção em permanecer na terra, permitindo a manifestação de práticas de resistência frente os obstáculos que se apresentam diariamente no caminho.

Em relação à reconhecida insuficiência do trabalho dos membros da família, ao trabalho dobrado dispendido por agricultores e agricultoras para dar conta daquilo que se coloca como intencionalidade primordial de suas práticas sociais (a luta para viver da terra), as formas de participação das mulheres e dos/as filhos/ as no cotidiano de roça parecem ter um papel fundamental para a compreensão de algumas das características do trabalho familiar realizado no Assentamento Santa Helena. Neste âmbito, entre os critérios adotados para divisão de tarefas no lote, ainda aparece de forma destacada nos dias atuais a insistente divisão sexual do trabalho que caracteriza a diferenciação das atribuições imputadas como obrigações masculina e feminina:

Eu gosto da roça. Se eu pudesse, não fazia nada dentro de casa. É a horta. Quando as meninas chegam aqui, limpa a casa, faz comida, lava roupa. Minha menina vem, quando está de férias. Eu falo pra eles: "Se eu pudesse ficava trabalhando só lá na roça" [...]. Quando chove, tudo, eu gosto de estar no meio do barro, mexendo. Meu forte é roça (Informação Verbal - Entrevista I $)^{9}$.

A divisão sexual do trabalho instituída por cada família em seus respectivos lotes caracteriza-se, conforme pudemos perceber nas falas femininas, pelo acúmulo de funções de natureza distintas desempenhadas pelas mulheres no cotidiano de reprodução da vida no assentamento, tais como o cuidado com filhos e filhas, o preparo do alimento, a limpeza da casa, a lavagem de roupa, aliados a realização

${ }^{9}$ Entrevista concedida por Ribeiro, Lindamira Aparecida Teodoro. Entrevista I [jun. 2017]. Entrevistador: D. M. T. São Carlos, 2017. 1 arquivo .mp3 (65 min.) 
de parte do serviço da roça dividido com seus maridos e, em parte, com os/as filhos/as. Em alguns casos, esta participação feminina no trabalho agrícola se restringe a algumas funções específicas que dele decorrem, tais como o beneficiamento de alimentos, a colheita, limpeza e preparação das hortaliças para realização das vendas, ou a própria atividade de comercialização em feiras livres.

Em outras situações, em especial àquelas para as quais o gosto pelo trabalho se expressa fundamentalmente quando estão realizando o serviço da roça, as mulheres também compartilham com seus companheiros a responsabilidade pela realização direta do manejo da terra para o plantio, ainda que tal partilha envolva uma divisão sexual entre serviços mais ou menos exigentes, sendo os trabalhos mais pesados atribuídos aos homens. Além do gosto pelo desempenho do trabalho agrícola e da obrigação dos afazeres domésticos, a definição acerca da participação feminina no arranjo familiar do trabalho ainda envolve a forma com que se concretizam as estratégias conjuntas pensadas em relação a capacidade de suprimento das atividades produtivas e reprodutivas do lote, podendo a contratação de mão de obra externa ser realizada, a depender da aptidão, do gosto e da necessidade de participação das mulheres em relação aos serviços da roça, para consecução dos serviços domésticos que no dia-a-dia acabam ficando para trás (ao invés do trabalho agrícola propriamente dito).

A medida da participação laboral dos/as filhos e filhas dos/as assentados/as que residem no assentamento e até mesmo fora dele também é diversa, dependendo se eles/as se encontram em idade escolar ou adulta, se intencionam ou não tocar o trabalho agrícola com os pais, ou se sua colaboração para reprodução familiar se dá por meio da obtenção de um trabalho externo que propiciará a obtenção de receita financeira própria e diminuirá, deste modo, a pressão sobre o custo de vida da família. No caso de se tratarem de filhos/as adultos/as que pretendem realizar o trabalho de plantio, a possibilidade de uma divisão mais equilibrada em relação à divisão e cumprimento de tarefas no lote é contraposta pela ampliação da necessidade de receita financeira a ser obtida por meio da comercialização dos produtos gerados no campo, dada a expectativa dos/as mais jovens em também gerar renda a partir do trabalho na terra. De qualquer forma, seja com auxílio nos serviços gerais e agrícolas do lote, seja com os salários obtidos em trabalhos diversos na cidade, o trabalho dos/as mais jovens no Assentamento Santa Helena constitui-se como elemento constitutivo da dinâmica de reprodução da vida familiar.

No caso específico de uma das mulheres assentada, que vive sozinha com sua neta em seu lote após a separação conjugal com o marido, a relação entre o acúmulo de funções, a insuficiência da mão de obra agrícola e a necessidade de geração de renda para sobrevivência da família constitui uma situação ainda mais prob- 
lemática e contraditória, dados os inúmeros conflitos de escolha que se colocam diariamente em seu horizonte de ações possíveis. Neste jogo entre necessidade/suprimento de mão de obra para o trabalho da roça e as estratégias de obtenção dos recursos financeiros mínimos para compra de itens de consumo, a baixa capacidade de provisão do trabalho desta assentada condicionada por sua condição de avó solteira vivente em um assentamento rural, aliada à necessidade que a impossibilidade de gerar receita por meio do produto do seu trabalho na roça suscita em relação à alienação de sua capacidade de trabalho, se conjuga com o indispensável suprimento da carência de mão de obra existente nos outros lotes do assentamento que possuem, esporadicamente, condições de contratar trabalhadores diaristas.

Neste caso, quem tem menor capacidade de trabalho se vê induzido a vender sua mão de obra para seus pares do próprio assentamento, satisfazendo precariamente uma e outra necessidade, visto que a renda gerada neste trâmite é insuficiente para que contratação mão de obra complementar no lote. Este "cobertor curto" utilizado como estratégia de sobrevivência pelos/as assentados/as revela, de modo dramático, a extrema dificuldade vivenciada pelos/as agricultores/as, muitas vezes em idade já avançada na vida e com problemas significativos de saúde, em fazer coincidir o trabalho na roça com o trabalho do sustento pleno pretendido. Assim, em relação a este aspecto, cada uma das famílias vai desenvolvendo seus próprios modos de lidar com tal questão e, de forma isolada, aprendendo a construir alternativas individualizadas que possam permitir gradativamente melhores condições de trabalho e de vida em seus lotes, a partir das situações e obstáculos que se apresentam cotidianamente na dinâmica de reprodução da vida no campo:

Eu prefiro arrumar alguém pra trabalhar nas diárias. Assim eu falo: "Você vai trabalhar pra mim a semana ou quinze dias". Aí eu sei que tenho o dinheiro pra pagar a pessoa. Porque mensal é mais difícil. Porque tem meses que você vende bem, tem meses que não. Por isso eu prefiro chamar de diarista, porque se tem o dinheiro pra três dias, eu pago, não tem eu chamo depois. Uma parceria seria legal, mas no início. No início, eu procurei parceria. Mas agora que já fiz mais da metade do trabalho, não vale a pena. Acho que no início ninguém acreditava. Quando eu falava que mexia com orgânico, a pessoa ficava desconfiada. Eu falava que era tudo natural, a pessoa ir embora e falava que voltava depois. Eu não vou falar que é uma pessoa ruim, porque eu também não acreditei. Tem que experimentar pra ver. Mas o mais difícil nós já passamos. No começo tinha bem pouca água, num tinha dinheiro pra comprar semente e tudo. No começo já procurei uma pessoa. Mas agora que já estamos bem, mais estabilizado, eu não tenho interesse mais nessa parceria. Agora que graças a Deus estamos muito 
bem, essa fase já passou (Informação Verbal - Entrevista II).

A fala destacada revela outros aspectos relacionados ao trabalho agrícola realizado no Assentamento Santa Helena. Primeiro, acerca da intenção comum entre os/as agricultores/as de buscar dar conta do trabalho da roça, ao máximo possível, no âmbito da própria família, acessando formas complementares de suprimento de mão de obra apenas e na medida da necessidade colocada em cada situação particular. Assim, para alguns/mas agricultores/as, vencido o período de formação do lote e das áreas de plantio, em que a escassez de recursos humanos, financeiros e hídricos tornava indispensável a busca por soluções estratégicas para o seguimento do trabalho (técnicas de plantio que minimizassem o manejo da terra, tentativa de viabilização de parcerias, etc.), iniciou-se um período em que a contratação e o aporte de mão de obra externa pôde ser pensada de forma pontual e esporádica, seja pela insegurança em relação ao retorno financeiro das atividades produtivas desempenhadas, cuja intermitência inviabilizaria a contratação de trabalho permanente, seja pela indisposição de agregar trabalhadores/as não habituados/as ao manejo da terra ou ao modo particular como cada família o realiza.

Por sua vez, toda a dedicação realizada objetivamente em relação ao trabalho no campo e suas formas específicas de concretização vai construindo, em cada agricultor e agricultora, percepções subjetivas diversas que refletem a maneira como significam suas distintas experiências laborais, passadas e presentes, e que vão engendrando o sentido e a intencionalidade de suas práticas sociais relacionadas à possibilidade de vida na terra:

Nossa, eu amo! Sempre eu fiz isso e sempre pensei isso aí. Sempre eu quis isso. Em todo lugar onde morei, sempre quis a mesma coisa. Desde o tempo que eles eram pequenininhos. Conseguia a charrete, a carroça primeiro. Nós levantávamos, colhíamos as coisas que tinha pra levar pra cidade. Em todos os lugares que moramos, sempre foi trabalho assim (Informação Verbal - Entrevista I).

Se fosse pra eu ficar aqui, eu saio no pensamento de que tô saindo e tem um mato pra tirar, tem coisa pra fazer. Eu tô lá e o pensamento está aqui. Lá eu não me sinto bem porque o pensamento está aqui. Minha esposa fala: "Você sai pra cidade já todo apavorado pra voltar". Eu falo: "Quero voltar porque lá está precisando de mim. Porque sem eu, está tudo parado lá". Se a gente estivesse alguém pra ajudar, pelo menos pra olhar, poderia ser que ficaria mais tranquilo na cidade. É corrido e preocupante a vida do produtor (Informação Verbal - Entrevista II). 
Mas é melhor que trabalhar para os outros. Eu vou falar pra você: eu criei nove filhos. Nove. Não é fácil. Eu já sofri muito. Você criar nove filhos, naquela Bahia, não é fácil não. Eu já vim molecote pra cá. Não é fácil não. Tem que ser homem. Tem que ser homem. Eu vou falar a verdade. Eu chegava sexta, ficava sábado, domingo. E sumia no mundo. Dormia no mato, no barraco. Nós só se via de fim de semana, em quinze dias, ou trinta dias. Eu criei, oito, nove. Eu já estou na hora de parar. Eu comecei a trabalhar desse tamanho (Informação Verbal - Entrevista VIII) ${ }^{10}$.

Para além dos aspectos relacionados à reprodução material da vida familiar problematizados anteriormente, a possibilidade de realização de um trabalho de cunho familiar permite a manifestação de processos educativos relacionados à valorização do trabalho empreendido na terra, na medida em que se manifesta o gosto e o prazer que sua realização permite expressar. Neste caso, ao contrário do que possa aparentar, a atribulada e corrida rotina de serviços realizados na roça traz sentimentos de tranquilidade e de sossego, por um lado, mas também de responsabilidade e comprometimento com os acordos e compromissos assumidos, relacionados à comercialização da produção agrícola e às necessidades de plantas e animais do campo, por outro. Este zelo empreendido com prazer e engajamento marca igualmente a possibilidade de realização de um trabalho desempenhado de modo autônomo que, a despeito da natureza desgastante do trabalho no campo e do cansaço presente em cada marca inscrita nos corpos mais ou menos envelhecidos, se apresenta como sinal de liberdade e autodeterminação.

\section{“MORAR EM CIMA dA TERRA E FICAR COMPRANDO, NÃo dá NÃo!”}

Se eu pudesse pagar uma pessoa pra me ajudar. Porque sozinha pra fazer tudo isso é duro. Tem coisas que eu não faço. Que não dá pra fazer. Que não aguento fazer. Fazer canteiro. Carpir eu carpo. Eu queria plantar feijão, milho. Eu planto, mas queria ter dinheiro pra gradear. Cercar do gado. Pra plantar feijão e milho. Porque morar em cima da terra e ficar comprando, não dá não! E feijão eu compro. Essa semana tive que comprar milho para as galinhas. Cinquenta conto no saco de milho. Elas estavam sem comida. Mandei trazer um saco de milho pra essas galinhas. Queria comprar mudas pra plantar mais coisas. Queria fazer um pomar de frutas aqui na frente. Tem que comprar as mudas. E eu queria plantar um pedaço de eucalipto (Informação Verbal - Entrevista IV).

\footnotetext{
${ }^{10}$ Entrevista concedida por Almeida, Honorina Nascimento; Almeida, Claudio Francisco. Entrevista VIII [jul. 2017]. Entrevistador: D. M. T. São Carlos, 2017. 1 arquivo .mp3 (128 min.)
} 
A condição de vida explicitada acima revela algumas conexões existentes entre as limitações presentes no modo com que se manifestam objetivamente as condições do trabalho familiar realizado no Assentamento Santa Helena e as relações e significações estabelecidas pelos/as agricultores/as no tocante ao processo de progressiva financeirização das formas de reprodução social em curso especialmente desde a década de 1990. A categoria "morar em cima da terra e ficar comprando, não dá não!” pretende abordar tais relações, enfatizando aprendizados decorrentes da tentativa de estabelecimento e consolidação de um modo de vida ligado a certas características que seriam distintivas do meio rural em relação ao urbano, tais como a valorização da possibilidade de obtenção do sustento direto da família por meio do trabalho na terra, com a consequente diminuição do custo de vida ordinário, e também o enaltecimento do ambiente salutar e tranquilo ali existente para a criação e o bem estar de filhos e filhas. Entretanto, a concretização destas experiências ligadas à vida do campo parece carecer fundamentalmente da obtenção dos requisitos financeiros necessários para sua realização, cuja utilização se faz indispensável tanto para o investimento produtivo inicial visando a formação das lavouras e dos lotes de trabalho (apenas parcialmente atendido pelo aporte de recursos monetários ofertados pelo INCRA no início do processo de constituição do assentamento), quanto para viabilização do suprimento da lacuna existente em relação à insuficiência de mão-de-obra presente em diferentes graus nos diversos lotes estudados:

Dinheiro. É, dinheiro faz tudo. Você tendo dinheiro... Como a gente, a crise de água. Se tivesse dinheiro, fazia um poço pra mim. Fazia um poço. Já me livrava bem, comprava bombas boas. Encanamento. É isso aí. Se você tiver dinheiro, melhor é. Mas se não tiver, você vai tocando do jeito que está. Igual nós vamos tocando (Informação Verbal - Entrevista III) ${ }^{11}$.

Mas não precisa pensar que precisa ter muita grana, que só rico tem isso e aqui. O Elio Neves falava que o povo dizia assim: "Quero começar lá mas não tenho maquinário, não tenho dinheiro". Ele dizia: "Deus já fez o ser humano. O homem fez o maquinário inspirado no ser humano". Ele mostrava: "Olha aqui, esse movimento da máquina, é o movimento das juntas dos ser humano. Todo o movimento que o maquinário faz, você também pode fazer. Não vai fazer na quantidade que o maquinário faz, mas você faz. Depois você consegue comprar uma carriola, depois consegue comprar uma roça. E você vai” (Informação Verbal - Entrevista VII).

\footnotetext{
${ }^{11}$ Entrevista concedida por Azevedo, Sebastião Alves. Entrevista III [jul. 2017]. Entrevistador: D. M. T. São Carlos, 2017. 1 arquivo .mp3 (23 $\mathrm{min}$.
} 
A contradição aparente existente entre as falas "dinheiro faz tudo" e "não precisa pensar que precisa ter muita grana", proferidas quando conversamos sobre as condições necessárias para se empenhar o trabalho na terra nos dias atuais, designa, em nossa compreensão, a distinção entre uma percepção que enfatiza as condições ideais de sua realização (a qual destaca a centralidade do dinheiro na realização dos investimentos que as proporcionarão), e outra que privilegia as condições mínimas necessárias para "ir tocando" a vida, centrada na capacidade de trabalho e empenho de cada agricultor e agricultora na labuta da roça, mas limitada pelo alcance possível de tal opção. Mesmo as estratégias agrícolas e pecuárias reconhecidas enquanto forma de realizar uma poupança não monetária, como são os exemplos do plantio de madeira (eucalipto) e da criação de gado de corte e leiteiro, exigem um investimento financeiro e produtivo inicial para, por exemplo, a construção de cercas, aquisição de mudas, suprimento de água, etc., o qual quase sempre está aquém das possibilidades de aplicação dos/as assentados/as.

Destarte, nossos dados de campo permitem afirmar que, ainda que a cesta de consumo das famílias brasileiras tenha se diversificado ao longo dos anos pela incorporação de bens industrializados e que a gama de produtos obtidos pelos/as agricultores/as diretamente pelo trabalho na terra tenha diminuído historicamente (especialmente pelo exaurimento dos solos disponíveis para plantio e pelo barateamento dos alimentos proporcionado pelo aumento da sua oferta ao longo do tempo, o que diminuiu a relação custo-benefício entre a produção direta de alguns itens de consumo e sua aquisição no mercado), a relação dos assentados com o dinheiro e a valorização que lhes imputam se dá principalmente enquanto meio de estabelecer de maneira resguardada e segura a possibilidade de consolidação da vida ligada à terra e ao campo:

É que a horta te dá rendimento mais rápido. Todas as outras coisas que a gente planta, a gente planta milho, plantamos feijão, estamos colhendo, estamos comendo o feijão novo. Mas a horta é a coisa que mais rende mais rápido. A horta te dá o dinheiro pra pagar as plantas e pra comer. Vi lá e vende. Pega, compra mercadoria. Aqui não dá o arroz e o açúcar. Então tem que comprar na cidade. E pagar a luz, água, umas contas. A gente compra arroz, café, óleo, uma mistura e das outras coisas, a gente tem por aqui. Um sabão, às vezes eu compro. A maioria faço o sabão do óleo que uso no salgado que vendo na terça feira. Faço sabão. Pouca coisa a gente compra na cidade. O restante a gente pega daqui (Informação Verbal - Entrevista I). Nós precisamos o que nós já temos pra viver. Está tranquilo assim. Apesar de, quando nossa produção está boa... Estamos organizando certinho. Precisamos melhorar mais nosso cronograma de entrega. Pra ter um valor mais 
exato no mês. Como estamos prematuros nisso tudo, estamos aprendendo. Mas a gente pretende ainda organizar bem certinho pra ter uma estimativa mais real. Tipo assim: vou vender $\mathrm{X}$ esse mês, $\mathrm{X}$ outro mês. Pra poder melhorar a produção. Pra ter um sistema de irrigação melhor. Coisas assim. Mas é pouca coisa. Nada que esteja assim, tão, longe. Está tranquilo assim. A gente não é de muita ambição. Somos simples mesmo. Não queremos ter muito dinheiro. Somos adaptados pra viver com quantidade pouca. Sem preocupação com o amanhã assim (Informação Verbal - Entrevista VII).

Se, por um lado, parte da necessidade financeira dos assentados advém da imperativa realização de investimento fixo e capital de giro para alavancagem e consolidação da produção agrícola, por outro lado as necessidades básicas de consumo não atendidas pelo cultivo de subsistência requerem uma liquidez cotidiana que ocasionam processos educativos relacionados ao planejamento do manejo produtivo com a terra, de modo que com ele se consiga suprir diariamente tais necessidades, seja pela escolha de um tipo de cultivo que promova rápido retorno financeiro de sua venda (horticultura), seja pela racionalização do cronograma de plantio e de entrega que venha a permitir a alocação mais equilibrada no tempo dos recursos auferidos por meio do comércio de hortifrútis. No entanto, considerando as condições limitadoras para realização do trabalho familiar existente na maior parte dos lotes estudados, aliadas às dificuldades de capitalização da produção agrícola, para alguns agricultores/as mesmo a obtenção mínima de dinheiro para suprimento destas necessidades básicas de consumo se constitui cotidianamente em incerteza.

Em nosso entendimento, esta necessidade de lidar com a escassez de recursos financeiros indica não apenas uma alta capacidade de adaptação em relação às condições materiais por vezes precárias que acompanharam estes sujeitos em boa parte de suas trajetórias de vida, mas também manifesta um modo próprio de compreensão da vida e do mundo, o qual se relaciona diretamente com a experiência junto à terra de trabalho destas mulheres e homens do campo e sua vocação aos serviços da roça:

Eu penso assim, você tem que fazer um trabalho não só pelo dinheiro. Está certo que ele precisa do dinheiro, da sobrevivência do dia a dia. No nosso mundo, precisamos do dinheiro também. Mas só que não é só o dinheiro. Porque se for fazer uma coisa só pelo dinheiro, uma coisa que faz com bronca, com raiva, não sai legal. Além do dinheiro, você precisa ter prazer no que faz. [...] Se fosse assim, nós ficamos aqui vários anos sem lucro. Até por doação. Se fosse assim, nós já teríamos parado, porque não entrava o dinheiro. Não paramos porque nós gostávamos. Fazia falta um pouco de 
dinheiro? Fazia sim. Mas é prazeroso pra nós, plantar, colher, lavar os produtos. Tem quem pode ver e pensar que é um suplício pra gente fazer essa trabalheira toda. Pensam que é um suplício. Mas não é. É prazeroso pra gente viver aqui (Informação Verbal - Entrevista VII).

Então, a gente estando na terra, a gente não precisa de muita coisa pra sobreviver. É só tudo ocorrer bem. Tudo dar certo. Com pouca coisa a gente vive na terra. Só com a família da gente está crescendo, a gente faz, pensando na família. Se minha família, pelo menos meus filhos, se eles não pegarem esse amor pela terra, explicando quais são as dificuldades e quais são as coisas que a terra dá pra gente, vai chegar uma época que eles não terão a mesma ideia da gente. Vão acabar desanimando, abandonado a terra e cometendo o mesmo erro que a gente fez. A gente fez por dificuldade e eles vão acabar fazendo por opção. Então, por isso, que eu explico as coisas certinho pra elas, né? Minhas filhas são todas mulheres. Que a gente tem como viver bem da terra. Enriquecer. Rico, milionário da terra, ninguém fica. Basta viver, ter o que comer e ter saúde. Não adianta ganhar um milhão e ter que gastar com sua saúde. Eu falo pra minhas filhas, nós nascemos com dificuldade financeira, mas nascemos ricos. Com saúde. Eu falo: "Olha nossa produção orgânica", sabe que é uma coisa boa que pode comer a vontade e não prejudica nada. Mantém a saúde da gente. Então, eu falo pra elas: "Porque você vai sair daqui pra ir pra cidade. Vai procurar o que lá? Se a maior riqueza nossa é o bem estar da gente, a saúde da gente". Você é saudável. Come do melhor. Está sabendo o que você está comendo porque é você quem está produzindo. Você come coisa saudável. Pode morrer de um acidente, ou porque um dia vamos ter que morrer mesmo, mas não por doença de agrotóxico, veneno. O importante nosso é viver com saúde. Se acontecer de elas abandonarem a terra, não vou poder fazer nada. Mas, nós aprendemos que as dificuldades na cidade são bem maiores que na roça, na terra. Por isso que eu vim de novo pra terra. Porque aqui, faltou alguma coisa, você sai ali e arruma. Na cidade não, se faltou na cidade, se você não tem dentro da sua casa, saiu na rua você tem que arrumar. Tem que se virar pra ter o que comer. Aqui, principalmente, pra comer, você sai ali na horta, pega alguma coisa. Faltou mistura, pega uma galinha caipira e mata. Pra mim, eu estou no céu. Estou no céu. Não preciso nem morrer (Informação Verbal - Entrevista II).

A valorização da vida na terra promovida pelos/as assentados/as está ligada, na maior parte dos casos, à possibilidade de realização de um trabalho que gera o alimento saudável para si e para os outros, mas também ao prazer e satisfação com que desempenham o próprio processo laboral agrícola, aprendido desde as infâncias 
vivenciadas com seus familiares na roça; aprenderam, igualmente, a relativizar a importância do dinheiro em suas vidas sem negar-lhe sua função fundamental para a reprodução social da vida familiar na atualidade, significando o "viver bem da terra" enquanto "viver com pouco e com riqueza de saúde", condição proporcionada pelo amor com que cumprem o trabalho do campo e com a garantia mínima de subsistência que ele propiciará. No âmago destas significações propostas pelos/ as agricultores e agricultoras com os/as quais pesquisamos, percebemos uma vez mais as marcas dos aprendizados gerados no decorrer de suas trajetórias de vida em relação às distintas formas de conscientização do contraditório vivenciado no seio de suas experiências de roça e de cidade.

Se, conforme nos disse um agricultor, "a gente tendo saúde, o resto à gente corre atrás” (Informação Verbal - Entrevista III), depreendemos de nossa análise que uma das principais preocupações dos/as assentados/as em relação à provisão financeira refere-se à sua capacidade de poupar tendo em vista futuras necessidades de gasto com saúde. Em alguns casos, para aqueles que conseguem realizar esta tarefa, tal economia de recursos é viabilizada pela complementação do orçamento doméstico proporcionada pelo recebimento de benefícios sociais diversos (bolsa família, aposentadoria, pensão, auxílio doença, etc.), a qual se soma à receita gerada pela renda agrícola. Para um dos agricultores, "sempre que dá para a gente juntar, não para enricar, porque a gente não enrica. Mas ter uns dois ou três contos lá no banco, precisa. Porque quando eu precisar, está lá, na hora de uma doença. Se você está com saúde, está aguentando. Você já tem tudo na horta” (EN VIII - US 54).

Outra indicação acerca da maneira precavida e criteriosa com que os/as agricultores/as aprenderam a lidar habitualmente com o dinheiro no Assentamento Santa Helena pode ser percebida por meio do modo com que significam e se relacionam com as possibilidades de obtenção do crédito agrícola disponíveis no mercado. Na visão dos/as assentados/as, dada a forma cautelosa com que aventam para a possibilidade de acessar recursos financeiros por meio de operações de crédito, ainda que elas se deem por linhas de empréstimo subsidiadas, melhor seria não depender de qualquer forma de crédito para atender suas necessidades de capitalização e consumo:

Assim, o único crédito que a gente pega é pra máquina grande. A caminhonete, a máquina de caldo de cana, o forno pra fazer pão. $\mathrm{O}$ PRONAF, de sete anos nós tem dois, só pra terminar de pagar. E é isso. [...] Não, a gente tenta andar nos trilhos. Se vamos fazer e depois não conseguir pagar, não. A gente tem que andar na altura que a perna alcança. Vamos devagar. Parece que vocês só pegam crédito a partir de um planejamento. Quando precisa do carro, vai e pega o carro. [...] Quando a gente fez 
o curso, o professor falou que o caldo de cana é bom de ter. Aí fomos, batalhamos, batalhamos e compramos o caldo de cana. Porque se não você fica enrolado, não tem nome, não consegue pagar. Não, não. Usamos o cartão de crédito. Eu tenho o meu e ele tem o dele. Mas usamos conforme dá pra pagar. Vamos comprar, vamos usar. É só o que a gente consegue pagar tudo (Informação Verbal - Entrevista I).

O receio de não cumprimento dos compromissos creditícios, possivelmente gerado pela incerteza em relação à geração de renda que propiciará seus pagamentos e ao retorno do investimento produtivo realizado, conduzem os/as agricultores/ as a ponderarem acerca da conveniência da consecução dos empréstimos financeiros tanto em relação a certo planejamento produtivo e à função cumprida por tais recursos para realização dos objetivos pretendidos, como pela avaliação da proporção entre o empréstimo a ser tomado e a estimativa de renda gerada no futuro. Buscam, com isso, "andar na altura que a perna alcança" e realizar um consumo apenas na medida da capacidade de pagamento de cada família, de modo a não incorrer em uma situação de inadimplência no mercado que obstrua o acesso a novos recursos para futuras necessidades de crédito.

Por outro lado, concretizado o acesso a alguma linha de crédito rural ou pessoal, os/as assentados/as engendram estratégias diversas de poupança de recursos, que vão desde o investimento em criações e plantações (no caso, gado e eucalipto) que proporcionem um retorno seguro do dinheiro investido, até a autoimposição de certo ascetismo no consumo de bens, o qual se expressa pela maior ou menor capacidade que cada pessoa possui de lidar com seus próprios desejos e necessidades. Destarte, diante do receio em tomar crédito e não conseguir pagar, dada a instabilidade das fontes de rendas disponíveis, a importância do papel da assistência técnica rural para orientação e acompanhamento dos projetos produtivos envolvidos com a obtenção do crédito revelou-se como condição facilitadora de promoção do acesso seguro a ele. Entretanto, num contexto marcado pela ausência de assistência técnica proporcionada pelo INCRA e pela carência de mão-de-obra familiar, alguns assentados vacilam entre a necessidade e a intenção de acessar o PRONAF e o receio de pegar o crédito e não ter condições de quitá-lo.

Em relação às formas de comercialização disponíveis e acessados pelos/as agricultores/as assentados/as, segundo seus próprios relatos (cf. ARRUDA, 2017), no ano de 2015 eles ainda não acessavam os canais de comercialização institucionais abertos com o Programa de Aquisição de Alimentos (PAA) e o Programa Nacional de Alimentação Escolar (PNAE)12, ambos operacionalizados pela Prefeitura

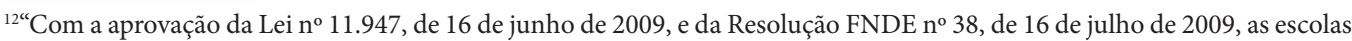
das redes públicas de educação básica passaram a usar produtos da agricultura familiar nas refeições oferecidas aos seus alunos. Agora, no mínimo 30\% do valor enviado a estados, municípios e Distrito Federal pelo Fundo Nacional de Desenvolvimento
} 
Municipal de São Carlos. Conforme apontado anteriormente, uma das primeiras dificuldades encontradas pelos/as agricultores do Assentamento Santa Helena para comercialização dos produtos agrícolas gerados no assentamento referiu-se à deficiências em relação às condições necessárias e suficientes para a realização plena do cultivo de hortaliças e grãos, manifestadas de forma diferenciada e desigual nos distintos lotes. Isto, por sua vez, incorreu na instabilidade da provisão de alimentos em escala comercial possibilitado pelo trabalho agrícola e na consequente insegurança dos agricultores para o estabelecimento de contratos de venda, públicos e privados.

No ano de 2016, a partir do início do trabalho de intermediação entre assentamento e poder público municipal realizado pela filha de uma assentada e seu esposo, ambos formados como agrônomos pelo Programa Nacional de Educação na Reforma Agrária (PRONERA), o grupo de oito famílias de agricultores orgânicos aglutinados em torno da Organização de Controle Social ali constituída passou a estabelecer e aumentar, gradativamente, sua participação nas vendas para os programas de compras públicas anteriormente citados. Entretanto, percebemos que esta ampliação da participação dos produtores orgânicos do assentamento nas receitas geradas não se deu de forma igualitária, sendo que os/as agricultores e agricultoras que possuem idade mais avançada e/ou possuem menores condições de suprirem as deficiências de água para irrigação e de mão de obra (elementos que podem ou não atuar de forma cumulativa) foram proporcionalmente menos beneficiados pelo recebimento dos valores obtidos com as vendas públicas.

Neste contexto, alguns/mas agricultores e agricultoras decidiram não arriscar o estabelecimento de tais contratos (em termos da quantidade e diversidade de produtos comercializados por meio deles), ação decorrente justamente dos limites impostos pelas condições produtivas existentes em seus lotes familiares e pelo receio de rescisão contratual do projeto de venda de todo grupo em caso do não cumprimento do cronograma de entrega dos produtos previsto no acordo firmado com os órgão públicos. Assim sendo, quanto menor a participação dos/as agricultores/ as em relação às vendas públicas institucionais, maior a necessidade de diversificação dos canais de comercialização por eles/as acessados a fim de que consigam escoar o excedente de produção e obter uma renda com o trabalho agrícola que seja minimamente suficiente para reprodução da família. Ainda assim, esta é uma condição desejável mesmo para aqueles/as assentados/as que auferem maiores receitas com os programas de compras governamentais, dada a inconveniência de

da Educação para o Programa Nacional de Alimentação Escolar (PNAE) devem ser utilizados obrigatoriamente na aquisição de gêneros alimentícios provenientes da agricultura familiar e do empreendedor familiar rural com dispensa de licitação. Em 2010, o orçamento mínimo do FNDE destinado exclusivamente à compra desses produtos é de R $\$ 900$ milhões" (BRASIL, s/d, p. 02). 
depender de uma única forma de comercialização sujeita à aprovação política e destinação de parte do orçamento federal para sua viabilização, não se apresentando, no médio e longo prazo, como um canal de venda totalmente seguro.

Como outras opções para comercialização de seus produtos, além das entregas de alimentos previstas nos contratos públicos, aparecem de forma destacada a participação de alguns/mas produtores/as em feiras livres da agricultura familiar, a venda direta realizada por meio de um sistema de entregas de cestas de hortifrútis do próprio assentamento a consumidores/as fidelizados/as, a vendagem in loco nos lotes de trabalho, o atendimento de encomendas avulsas realizadas por vizinhos/as ou colegas de trabalho de familiares que residem na cidade, e também o comércio estabelecido com pequenos varejistas do setor de orgânicos. Da mesma forma que as condições produtivas de cada lote interferem em sua capacidade de comercialização e geração de renda por meio do trabalho agrícola, a diferenciação entre os/as agricultores/as em relação à disponibilidade de meios de transportes para realização de entregas e feiras também se constitui num diferencial entre aqueles/as que podem ou não suprir tal necessidade, viabilizando ou não a efetivação dos canais de comércio disponíveis.

Assim, este conjunto de distinções presentes e manifestadas no cotidiano de trabalho e de vida na terra dos sujeitos da pesquisa engendram entre eles/as, no interior da consecução de suas estratégias de comercialização, aprendizados relacionados à solidariedade com que realizam uma série de práticas de colaboração e ajuda mútua, tais como: a realização da venda dos produtos daqueles que não possuem meio de transporte para participar das feiras, a disponibilização de parte da produção agrícola excedente (por meio de doação, troca, consignação, participação percentual na venda) para aqueles/as com maiores dificuldades de produção, ou ainda a cobertura de entregas previstas em contrato que, em caso de problemas produtivos diversos (pragas, frio, muita chuva, baixo desenvolvimento da planta), não poderão ser realizadas pelo/a agricultor ou agricultora responsável.

Deste modo, em meio às relações de tensão estabelecidas com a economia de mercado no que tange as formas possíveis de reprodução social da vida no campo, os/as assentados/as permanecem aprendendo a lutar, simultaneamente, contra a necessidade de obtenção e a favor da possibilidade de usufruto do dinheiro, na medida em que tal recurso pode permitir o desenvolvimento e a consolidação da vida no meio rural sem afetar essencialmente suas visões de mundo, as quais valorizam e significam positivamente as relações de trabalho na terra, a possibilidade do consumo de alimentos sem veneno e a saúde e bem estar de suas famílias, condição finalmente obtida após anos de batalha. 


\section{"DEVOLVER SAÚDE PRA TERRA"}

A gente espera que muitos, muitos produtores comecem a plantar orgânico. Porque, antigamente, quase não tinha câncer. Antigamente não existia essas facilidades que tem hoje que não precisar sair. Tem esses produtos que você passa em cima da planta, ele mata o mato e a planta fica ali. Quer coisa melhor? É difícil produzir orgânico? É! É uma batalha que você tem ali. É sacrificado, mas é prazeroso, porque você sabe que está produzindo coisas boas pra quem vai consumir. [...] A gente planta flores, pra atrair os insetos. Dá pra fazer. O custo está na mão de obra. Os insumos e compostos que você usa, são bem mais baratos que o adubo, mas é um processo demorado, longo, que vale a pena. Plantar flores e árvores pra devolver saúde pra ter$r a$. Além da vantagem dos filhos e netos crescer ali, sabendo que não pode fazer queimada, usar veneno. É isso (Informação Verbal - Entrevista VI).

A construção da categoria “devolver saúde pra terra” pretende designar a intencionalidade presente nas práticas agrícolas empenhadas pelos sujeitos de nossa pesquisa, os/as quais escolheram promover em cada um de seus lotes no Assentamento Santa Helena um modo de plantio orgânico, sem utilização de agrotóxicos e adubos químicos sintéticos. Até o momento, enfatizamos as significações propostas pelos/as assentados/as sobre a experiência educativa do trabalho na roça em relação ao papel cumprido por ele para obtenção de parte do sustento direto das famílias, engendrando tanto material como simbolicamente a valorização desta forma de reprodução social caraterística do meio rural.

Neste momento, o que designamos enquanto luta pela terra vai adquirir um sentido mais amplo, o qual não se restringirá à batalha pelo direito de obtenção ou sustentação de um pedaço de chão cujo manejo possibilitará o alimento posto à mesa da própria família, mas remeterá simultaneamente ao zelo empreendido a partir do cuidado amoroso com a terra, compreendida enquanto bem natural indispensável tanto para produção agrícola quanto para a reprodução da vida da fauna e da flora terrestre, e não apenas como mero fator de produção e especulação financeira. Devolver a saúde para terra assinala, igualmente, a responsabilização dos/as agricultores/as em relação à saúde de outrem, manifestada pela preocupação, compromisso e gosto com que produzem os alimentos que serão comercializados para consumidores diversos, além de sua família. Indicam, com isso, uma compreensão da vida e do trabalho do campo na qual saúde da terra e saúde das pessoas possuem mesma dimensão, de forma integrada e interdependente. Destarte, conforme depreendemos dos depoimentos recolhidos e transcritos a seguir, boa parte desta forma de relacionar-se com a terra de trabalho foi apreendida e significada pelos aprendizados decorridos das experiências de roça 
vivenciadas na infância, a partir do modo tradicional com que pais e avós realizaram, no passado, o manejo agrícola no campo:

A decisão é essa que eu tomei. Falei que nós nascemos no campo. Onde nós nascemos e criemos no estado da Bahia, não existia produtos químicos. Fomos criados nos alimentos sadios. Então, nós pensamos que poderíamos viver como a gente foi criado. Lá da Bahia, fui criado com lavoura boa, sem veneno. Então, você nasceu e criou comendo coisa saudável. Não era bom que continuássemos assim? (Informação Verbal - Entrevista VI).

A realização da coivara ${ }^{13}$ e a implantação das lavouras brancas sem a utilização de veneno, adubos sintéticos, maquinários e outros implementos agrícolas, remetem a práticas realizadas em tempos anteriores à intensificação do processo de modernização da base técnica dos meios de produção agrícolas, concretizado no campo brasileiro desde a década de 1950. Tal processo difundiu, por meio da expansão e institucionalização do serviço de assistência técnica e extensão rural no país, um modelo de agricultura baseado no aumento da produtividade em detrimento da intensividade da mão-de-obra, processo que ensejou a mudança de concepções e práticas de manejo tradicionalmente utilizadas por agricultores e agricultoras e estimulou a aquisição de insumos industriais nos sistemas produtivos do campo, utilizados num primeiro momento especialmente nas lavouras permanentes, mas que logo se expandiu para os demais tipos de cultivo agrícola.

Para a maior parte dos/as agricultores/as entrevistados/as, o regresso a terra após anos dedicados a trabalhos temporários no campo e na cidade possibilitou a recuperação de certas práticas agrícolas tradicionais que, atualmente, a partir da conjuntura histórica de progressivo questionamento em relação à utilização desmedida de agrotóxicos e adubos sintéticos ${ }^{14}$, bem como aos impactos ecológicos e para a saúde humana verificados nas últimas décadas (erosão e a perda da fertilidade dos solos, destruição florestal, dilapidação do patrimônio genético e da biodiversidade, contaminação dos solos, da água, dos animais silvestres, dos alimentos e dos seres humanos), se investem de outras nomenclaturas e novas significações ${ }^{15}$. Para outros/as assentados/as, entretanto, a possibilidade de

\footnotetext{
13“'O termo 'coivara', de origem indígena, significa empilhar e tornar a queimar troncos e galhos não consumidos em uma primeira queima. Populações tradicionais - indígenas e não indígenas - de regiões tropicais do planeta ainda adotam o chamado cultivo de coivara, também conhecido como 'cultivo de corte e queima'. O sistema é encontrado hoje em diversas regiões do mundo, inclusive no Brasil, na Amazônia e em áreas de mata atlântica” (NEVES et al, 2012, p. 26).

${ }^{14 “ N a}$ última década, o Brasil expandiu em 190\% o mercado de agrotóxicos, o que colocou o País em primeiro lugar no ranking mundial de consumo desde 2008. Dez empresas controlam mais de $70 \%$ desse mercado no País. Somente na safra de 2010 e 2011, foram consumidas 936 mil toneladas de agrotóxicos” (LOPES; ALBUQUERQUE, 2018, p. 519). Para outras informações sobre o tema, ver também o trabalho de Mazzoleni; Nogueira (2006).

${ }^{15}$ “O termo agricultura orgânica é utilizado de forma generalizada nos principais países do mundo. Mencionado em
} 
realização de um plantio orgânico não se encontrava disponível em seus horizontes de escolha antes da chegada ao assentamento, dada a experiência pregressa de manejo agrícola essencialmente ligada à utilização habitual e indiscriminada de agrotóxicos, e visto o desconhecimento das consequências de tal procedimento para a saúde humana e ambiental:

Veio os cursos, veio os orgânicos. Porque a gente nem imaginava que poderia tira alguma coisa sem o adubo químico e sem o veneno. Eu já fui intoxicado com veneno. Já lidei com vários tipos de pragas na lavoura, no café, algodão, amendoim. E nem o veneno químico dava conta. Quando falaram do orgânico eu não conhecia. Quando falaram que era um produto que não vai nada químico, não põe adubo químico, não põe veneno, é tudo com matéria orgânica, eu pensei: "Isso aí não existe." (risada) Porque eu venho do plantio convencional. Fui criado vivendo com a bomba de pulverizador nas costas. Pulverizava de dia e de tarde. O café, pra ferrugem, pra um monte de coisa. Aí perguntaram se eu queria fazer o curso, eu falei: "Fazer eu quero". Conhecer tudo que é para as melhorias, eu quero fazer. Aí no decorrer do curso que fui tendo os conhecimentos, foi fazendo sentido. Aí falei: "Eu creio que dá certo. Desse jeito tem sentido". E fomos adquirindo conhecimento, aprendendo. Fomos mexendo. Aí no final do curso, minha ideia já era outra. "Pelo menos vamos tentar mexer com orgânicos". Aí comecei a fazer, aprendendo os produtos naturais. Fomos fazendo os primeiros canteiros, fomos tendo bons resultados. Plantando alface, almeirão, coisas que não dão muita praga. Depois fomos tentando outras coisas (Informação Verbal - Entrevista II).

Os cursos de formação técnica para a produção orgânica de alimentos oferecidos aos agricultores/as do Assentamento Santa Helena por agentes sociais diversos ao longo de sua história desempenharam um papel fundamental em relação à decisão e à viabilidade da implantação do cultivo orgânico em seus lotes de trabalho. Assim sendo, aparecem de forma destacada na fala dos sujeitos de pesquisa a realização, em 2013, do curso de Olericultura Orgânica e do Programa de Certificação de Agricultura Orgânica, ambos implementados pelo SENAR/SP em parceria com o MAPA.

De outra maneira, a formação de nível superior em agronomia conquistada

documentos oficiais de organismos internacionais (ONU, UNCTAD, FAO), é também encontrado na legislação brasileira, desde a Instrução Normativa № 7, 17/05/1999, consolidando-se com a recente Lei 10.831, de 23/12/2003. [...] Não obstante, o avanço do sistema orgânico propriamente dito ocorreu no Brasil a partir de 1992. Hoje, o termo agricultura orgânica possui uma conotação nova e mais abrangente. Nesta condição, a expressão 'agricultura orgânica' abrange todas as demais definições que atentem para o problema de desenvolver a agricultura de forma economicamente viável, socialmente justa e ambientalmente correta" (MAZZOLENI; NOGUEIRA, 2006, p. 269). 
pela filha de uma assentada por meio do PRONERA possibilitou uma troca de conhecimento intergeracional entre pais agricultores/as e filha agrônoma que permitiu, assim como a realização de outros cursos de capacitação e formação profissional, aprendizados fundamentais no tocante à aspectos técnicos da produção agrícola em sistema orgânico, como também a conscientização em relação às consequências maléficas para a saúde humana e para o meio ambiente do uso indiscriminado de agrotóxicos. Entre o conhecimento tradicional e o científico, a problematização de tais elementos esteve significativamente presente na intencionalidade primordial para efetivação das primeiras tentativas de plantio orgânico dos/as agricultores/as, o que por sua vez atendeu em parte as exigências normativas relativas aos critérios para o manejo da terra em assentamentos da modalidade Projeto de Desenvolvimento Sustentável.

Ainda que a indisponibilidade de recursos financeiros tenha sido, em alguns casos, um elemento de promoção inicial de um plantio sem a utilização de insumos industriais convencionais, dada a precariedade das condições de reprodução da vida vivenciadas no início do processo de constituição do PDS, o cuidado com o próprio corpo, o zelo com o bem-estar da família e de outrem, e a preocupação com a saúde da terra foram se constituindo enquanto princípios orientadores das ações de manejo e trabalho agrícola desempenhado pelos/as assentados/as em seus lotes, processo que se deu a partir tanto do resgate dos aprendizados experienciados anteriormente no campo quanto da incorporação de novos saberes adquiridos com a vivência no assentamento rural.

Entretanto, as dificuldades ainda presentes em relação à possibilidade de traduzir tais princípios em ações produtivas viáveis nos indica que são necessários requisitos que vão além da firmeza de intenção dos/as agricultores/as em suas práticas agrícolas: requerem, além de condições de infraestrutura e investimento adequadas, acompanhamento e orientação técnica por parte das agências de assistência técnica e extensão rural contratadas pelo INCRA. Entretanto, segundo Gonçalves (2015):

Nos assentamentos rurais de reforma agrária, as discussões sobre a precariedade e os limites dos recursos para a assistência técnica não são novas. Entretanto, os problemas relativos a este tipo de serviço tornaramse mais complexos à medida que as questões ambientais passaram a ser incorporadas aos projetos de assentamentos rurais. Simplesmente, não há profissionais qualificados em quantidade e qualidade suficiente para cobrir a demanda requerida pelos processos de transição agroecológicos; além disso, é preciso considerar que cada agroecossistema tem suas especificidades e isto exige investimentos de médio e longo prazo, algo que, infelizmente, não faz parte dos editais de ATER publicados pelo INCRA (p. 176). 
Considerando e problematizando tais dificuldades, os/as assentados/as buscam criar e colocar em prática diariamente estratégias de manejo e aprendizados que visam superar a ausência de suporte técnico para o cultivo orgânico, descobrindo formas de lidar com a terra esgotada pelos anos de exploração monocultora e rentista com base na própria experiência reflexiva que constituí o cotidiano de trabalho:

E foi muito difícil, porque pegamos uma terra que foi muito judiada. Demoramos muito tempo pra corrigir essa terra. Pegamos uma terra que foi zerada. Agora, tudo que você planta nela dá. Dá uma diferença muito grande. Mas, no início, você plantava uma planta, principalmente as plantas de folha larga. Porque a cana é de folha estreita, então passavam coisas pra não nascer planta de folha larga. Então, você plantava e nem nascer nascia. Muita coisa que eles passavam na terra de coisas químicas. Praticamente, só depois de 7, 8 anos que percebemos que a terra deu uma melhorada. Que a gente foi ver dar alguma coisinha. Mas vencemos. Vencemos, estamos aí. Graças a Deus (Informação Verbal - Entrevista II).

Vai aprendendo um pouco. Devagarinho vai ver se não dá pra fazer um plantio grande, faz um pequeno. Pra aprender a lidar com o solo do local. Às vezes, o milho por exemplo, é acostumado com um solo do outro estado, ali plantava bem. Aí vem aqui, não precisa corrigir tanto a terra. É um aprendizado. A gente nunca para de aprender. O plantio, todo dia você está aprendendo com a planta. Não tem como a pessoa pensar que já sabe tudo. Porque muda o solo, muda a estação. Uma propriedade como essa, de 3 alqueires, a parte de lá o solo é assim, na parte de cá e outra. Lá uma planta não foi bem aceita, aqui foi. O tipo de semente. Tudo isso (Informação Verbal - Entrevista VII).

A partir da confrontação das experiências pregressas com a realidade atual vivenciada no assentamento, ocorrida no bojo da construção cotidiana de suas compreensões acerca do modo como se manifestam as relações objetivas e subjetivas entre trabalho agrícola e natureza, os/as agricultores/as assentados/as aprenderam a significar o trabalho na roça e a temporalidade envolvida nesta relação prático-produtiva de provimento do sustento por seu intermédio, assim como os atributos valorizados para a permanência e persistência das pessoas no campo. Deste modo, ainda que reconheçam nos aprendizados do passado uma condição facilitadora para lidar com experiência presente (marcada pelas adversidades e tensões existentes para a constituição e consolidação de um assentamento agrário no seio do processo de produção e reprodução social capitalista brasileiro), os/as agricultores/as puderam perceber em suas experiências o caráter perene dos pro- 
cessos educativos gerados a partir das práticas agrícolas com as quais manejam a terra de trabalho, nos indicando o que vem aprendendo nestes tempos de assentamento: a prudência do plantio em menor escala como estratégia de reconhecimento das características do solo e dos vegetais, a importância da perseverança para realização de trabalhos que frutificarão apenas no médio ou longo prazo, a valorização da sensibilidade inerente ao sentimento de amor com que cuidam da terra, a noção de que tudo na natureza tem seu espaço, seu tempo, sua precisão.

Por fim, a satisfação de fazer o que se sabe e o que se gosta de fazer, mesmo consciente do pouco retorno financeiro gerado em relação ao trabalho árduo realizado, se expressa por sua vez no cuidado com que os/as assentados/as empenham o cultivo, a colheita e comercialização de seus produtos agrícolas, visto que, conforme entendem o exercício do trabalho na roça, "não é só vender e ganhar um troquinho lá. É a vida do outro que interessa. O que interessa é a vida do outro" (Informação Verbal - Entrevista VI).

\section{CONSIDERAÇões}

Por meio da análise fenomenológica de dados empíricos, buscamos neste artigo fornecer elementos interpretativos relacionados às tensões vivenciadas nos últimos anos desta década pelos/as agricultores/as orgânicos/as do Assentamento "Projeto de Desenvolvimento Sustentável Santa Helena", implantado em 2005 no município da São Carlos/SP, no que tange às formas de trabalho engendradas no assentamento, às relações comerciais e financeiras estabelecidas pelos agricultores/as em seu cotidiano de vida e também à forma com que significam o manejo orgânico da terra. Ao longo do texto, argumentamos que a valorização da terra como meio de vida apresenta-se no presente como força motriz das práticas sociais vivenciadas pelos/as agricultores/as que buscam consolidar-se, no referido assentamento, enquanto produtores de alimentos orgânicos, livre da presença de agrotóxicos e outros componentes sintéticos que minam gradativamente a saúde da terra e das pessoas.

Forjado no decorrer de vidas inteiras dedicadas à luta, tal princípio não se encontra alheio aos dilemas e contradições decorrentes da condição de agricultor/a assentado/a no país do agronegócio. Assim, enquanto prática social geradora de processos educativos, a luta pela terra como meio de vida encontra sua expressão final no processo continuado de recriação de constrangimentos que em parte caracteriza a condição camponesa presente no PDS Santa Helena e também em outros assentamentos rurais contemporâneos.

Conforme propomos, entre a significação de tal fenômeno e suas possibilidades de superação, entre a realidade vivida e a realidade sonhada pelos sujeitos 
assentados, vai se constituindo historicamente a condição camponesa no Brasil. Revela, a seu modo, o imbricamento existente entre a prática da luta pela terra como meio de vida e o processo de educação humana, manifestando a indissociabilidade entre a experiência humana de significação do mundo cultural e constituição de identidades, e os sentidos e as direções objetivas assumidas pelos processos sociais que constituem historicamente nossa realidade objetiva comum. Considerando que tal realidade pode ser compreendida de modos diversos pelos indivíduos, desde as relações intersubjetivas que permeiam tal entendimento, o ato de se educar com a luta pela terra se configura como próprio a cada pessoa, ainda que seja um processo de criação tão individual quanto social.

Destarte, reconhecendo o caráter inacabado da construção histórica, encontramos nas intencionalidades presentes no envolvimento desta população marginalizada em processos de resistência e disputa pela posse da terra, seja em seu desejo de permanência ou de regresso a ela, elementos essenciais para compreensão dos modos de manifestação do fenômeno da luta pela terra no país, tendo na organização coletiva dos movimentos reivindicatórios em prol da reforma agrária uma de suas formas de expressão contemporâneas mais importantes. Constituem-se, assim, experiências de luta intrincadamente costuradas com as diferentes trajetórias de vida dos sujeitos do campo, engendrando a ocorrência de processos educativos que, para além das distintas realidades de ação e dominação vivenciadas, são capazes de gerar e instituir identidades, valores e atitudes que lhes são comuns.

\section{REFERÊNCIAS}

ARRUDA,T.P.de.AvaliaçãodaSegurançaAlimentareNutricionaldeagricultores familiares do Projeto de Desenvolvimento Sustentável Santa Helena de São Carlos-SP. Dissertação (Mestrado) -- Universidade de Araraquara, Araraquara, 2017.

BRANDÃO, C. R.. A educação como cultura. Campinas: Mercado de Letras, 2002.

BRASIL. Ministério do Desenvolvimento Agrário. Portaria n. 21, de 27 de março de 2014. Alterada pela Portaria n. 33, de 15 de maio de 2014, publicada no DOU n. 91, de 15 de maio de 2014. Disponível em: http://www.mda.gov.br/sitemda/sites/sitemda/files/user_arquivos_64/PORTARIA_MDA_21_DAP_-_ALTERADA_33_-_22.05.2014.pdf. Acesso: 15 de novembro de 2018.

Ministério do Desenvolvimento Social e Combate à Fome. Programa 
de Aquisição de Alimentos da Agricultura familiar. Renda para quem produz e comida na mesa de quem precisa. 2010. Disponível em: http://www.mda.gov. br/sitemda/sites/sitemda/files/user_arquivos_64/CARTILHA_PAA_FINAL.pdf. Acesso: 21 de novembro de 2018.

. Ministério da Educação. Cartilha Alimentação Escolar e Agricultura Familiar. Brasília: FNDE/MEC, sem data. Disponível em: https://www. fnde.gov.br/programas/pnae/pnae-area-para-gestores/pnae-manuais-cartilhas/ item/5169-cartilha-alimenta\%C3\%A7\%C3\%A3o-escolar-e-agricultura-familiar. Acesso: 21 de novembro de 2018.

FERRANTE, V. L. S. B.; BARONE, L. A.; DUVAL, H. C. O final de um ciclo? Reflexões sobre assentamentos rurais no Estado de São Paulo. REDD - Revista Espaço de Diálogo e Desconexão, v. 5, n. 1, jul/dez. 2012.

GARNICA, A. V. M. S. Algumas notas sobre pesquisa qualitativa e fenomenologia. Interface - Comunicação, Saúde, Educação, v.1, n.1, 1997.

GONÇALVES, J. C. Desenvolvimento sustentável e questão agrária: retóricas e realidades em movimento. Tese (Doutorado) -- Universidade Federal de São Carlos, São Carlos, 2015.

LEOPOLDO E SILVA, F. Descontrole do tempo histórico e banalização da experiência. In: NOVAES, A. (Org.) Mutações: ensaios sobre as novas configurações do mundo. São Paulo: SESC - Agir, 2008, p. 149-162.

LOPES, C. V. A.; ALBUQUERQUE, G.S.C.de. Agrotóxicos e seus impactos na saúde humana e ambiental: uma revisão sistemática. Saúde em Debate, 2018.

MAZZOLENI, E. M.; NOGUEIRA, J. M.. Agricultura orgânica: característica básica do seu produtor. Revista de Economia e Sociologia Rural, v. 44, 2006.

NEVES, W. A et al. Coivara: cultivo itinerante na floresta tropical. Ciência Hoje, v. 50, 2012.

OLIVEIRA, M. W. de. Et al. Processos educativos em práticas sociais: reflexões teóricas e metodológicas sobre pesquisas em espaços sociais. In: OLIVEIRA, M. W. de; SOUSA, F. R. (Org.). Processos educativos em práticas sociais: pesquisas em educação. São Carlos, SP: EdUFSCar, 2014, p. 29-46. 